\title{
Photolytic Processes for Measurement of Combustion Heats of Formation and Reaction Rates
}

Investigators: Dr. Joshua B. Halpern

Dr. Hideo Okabe

Department of Chemistry

Howard University

Washington, DC 20059

(202) 806-6895

Source of Support: Department of Energy

DE-FG05-85ER1388

\section{DISCLAIMER}

This report was prepared as an account of work sponsored by an agency of the United States Government. Neither the United States Government nor any agency thereof, nor any of their employees, makes any warranty, express or implied, or assumes any legal liability or responsibility for the accuracy, completeness, or usefulness of any information, apparatus, product, or process disclosed, or represents that its use would not infringe privately owned rights. Reference herein to any specific commercial product, process, or service by trade name, trademark, manufacturer, or otherwise does not necessarily constitute or imply its endorsement, recommendation, or favoring by the United States Government or any agency thereof. The views and opinions of authors expressed herein do not necessarily state or reflect those of the United States Government or any agency thereof.

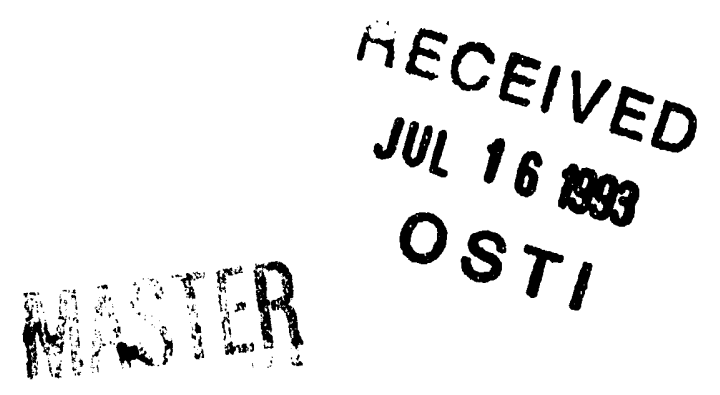


FINAL REPORT

This project includes measurements of the kinetics, fiuorescence spectra and thermochemistry of alkoxy radicals which are important species in the combustion of hydrocarbons. Ro radicals were produced by the laser photolysis of RONO.

In order to measure the kinetics of alkoxy radicals previous workers used frequency doubled tunable dye lasers [1-4]. In the course of this project we discovered that the $337 \mathrm{~nm}$ nitrogen laser nm can be used to excite laser induced fluorescence (LIF) from many of the most important alkoxy radicals. The nitrogen laser is less expensive and much simpler to operated than a high power dye laser which is needed if one is to have sufficient flux after frequency doubling into the UV region. Alkoxy radicals were produced by the $355 \mathrm{~nm}$ photolysis of RONO precursors. We were able to detect LIF signals from $\mathrm{CH}_{3} \mathrm{O}, \mathrm{C}_{2} \mathrm{H}_{5} \mathrm{O}, \mathrm{i}-\mathrm{C}_{3} \mathrm{H}_{7} \mathrm{O}, \mathrm{n}-$ $\mathrm{C}_{3} \mathrm{H}_{7} \mathrm{O}, t-\mathrm{C}_{3} \mathrm{H}_{7} \mathrm{O}$, and $t-\mathrm{C}_{4} \mathrm{H}_{9} \mathrm{O}$ using nitrogen laser excitation. For $i-\mathrm{C}_{3} \mathrm{H}_{7} \mathrm{O}$ in particular we have measured rate constant with No, $\mathrm{O}_{2}$, $\mathrm{CO}, \mathrm{CH}_{4}$ and $\mathrm{H}_{2}$. The measured rate constant with $\mathrm{NO}$ is $2.69 \times 10^{-}$ 11; and with $\mathrm{O}_{2}$ it is $9 \times 10^{-15} \mathrm{~cm}^{3} /$ molec-s. Against the other species the reaction rate constants are less than $10^{-15}$ $\mathrm{cm}^{3} / \mathrm{molec}-\mathrm{s}$. Its collision free lifetime is $0.64 \pm 0.09$ microseconds and the quenching rate constant of the excited radical by $\mathrm{i}-\mathrm{C}_{3} \mathrm{H}_{7}$ ONO is $3.54 \pm 0.38 \times 10^{-10} \mathrm{~cm}^{3} / \mathrm{molec}^{-}$.

Dispersed fluorescence spectra were measured following photolysis of $\mathrm{i}-\mathrm{C}_{3} \mathrm{H}_{7}$ ONO diluted in $\mathrm{He}$ at $193 \mathrm{~nm}$ which produced excited 
radicals. The $0-0$ band of the $\mathrm{i}-\mathrm{C}_{3} \mathrm{H}_{7} \mathrm{O}$ radical was found at 27140 $\pm 20 \mathrm{~cm}^{-1}$ and the ground state vibrational co stretch frequency was determined to be $960 \pm 20 \mathrm{~cm}^{-1}$. The radiative lifetime of the radical was measured to be $640 \mathrm{~ns}$ and its radiative quenching rate against the parent molecule was $3.54 \pm 0.48 \mathrm{~cm}^{3} / \mathrm{molec}^{-s}$.

A similar method was used to produce excited $n-\mathrm{C}_{3} \mathrm{H}_{7} \mathrm{O}$ ( radicals. The radiative lifetimes of excited $n-\mathrm{C}_{3} \mathrm{H}_{7} \mathrm{O}^{*}$ radicals is $700 \pm 80$ ns and the quenching rate constant of the excited radical by $n$ $\mathrm{C}_{3} \mathrm{H}_{7}$ ONO is $5 \pm 1 \times 10^{-10} \mathrm{~cm}^{3} / \mathrm{molec}-\mathrm{s}$. The fluorescence spectrum of the $\mathrm{n}-\mathrm{C}_{3} \mathrm{H}_{7} \mathrm{O}^{*}$ radical extends from 340 to $500 \mathrm{~nm}$, showing ground and excited state progressions in the co stretch. For the ground state the co stretch frequency is determined to be 1065 $\mathrm{cm}^{-1}$ and for the excited state it is $450 \pm 50 \mathrm{~cm}^{-1}$.

We attempted to produce alkoxy radicals by dissociation of a series of asymmetric ethers at $193 \mathrm{~nm}$, and by detecting the fragments with LIF using a doubled Nd-YAG pumped dye laser. This was not successful.

To determine the heats of formation of the alkoxy radicals we attempted to measure the threshold for production of excited RO* from the photolysis of RONO. The tunable light at about $200 \mathrm{~nm}$ was produced by Raman shifting doubled Nd-YAG pumped dye laser light. Measurements with $\mathrm{C}_{2} \mathrm{H}_{5} \mathrm{O}$ showed a threshold above $215 \mathrm{~nm}$.

We attempted to detect the second absorption system of $\mathrm{NH}_{2}$ by LIF in the far UV region. Again, this did not succeed. 


\section{REFERENCES}

1. N. Sanders, J.E. Butler, L.R. Pasternack and J.R. McDonald. Chem. Phys. Lett., 48 (1980) 203.

2. K. Lorenz, D. Rhasa, R. Zellner and B. Fritz, Ber. Bunsenges. Phys. Chem., 89 (1985) 341.

3. D. Gutman, N. Sanders, and J.E. Butler. J. Phys. Chem., 86 (1982) 66.

4. R.J. Balla, H.H. Nelson and J.R. McDonald. Chem. Phys., 99 (1985) 323 .

Publications resulting from this award:

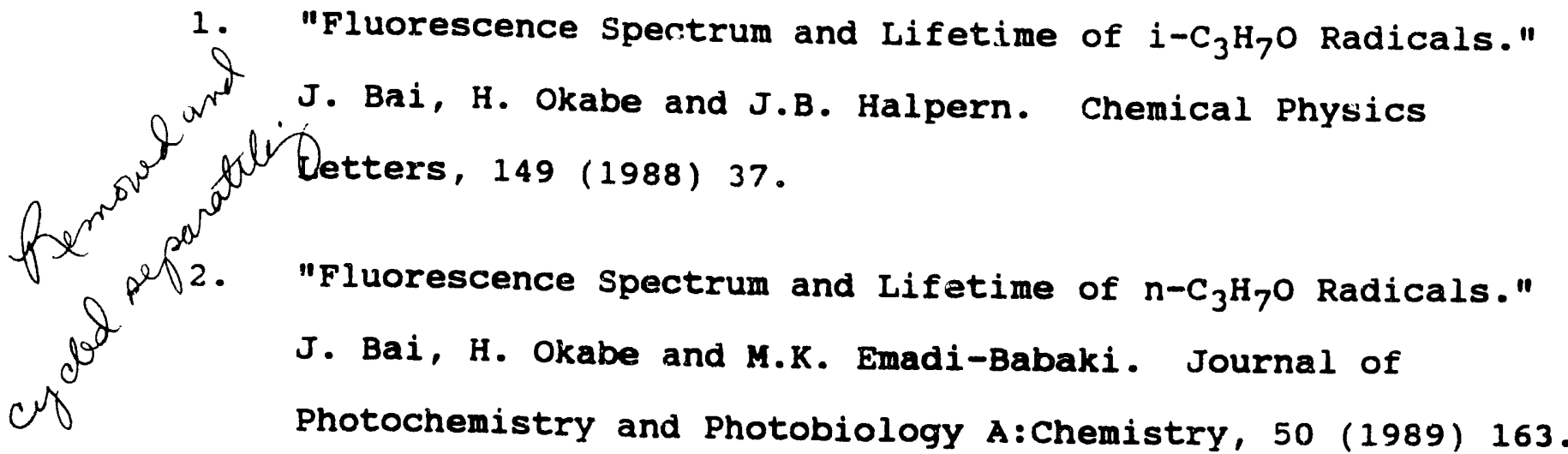

Thesis resulting in part from this award:

1. M.K. Emadi-Babaki, Ph.D., Physics, Howard Unversity, 1991. 

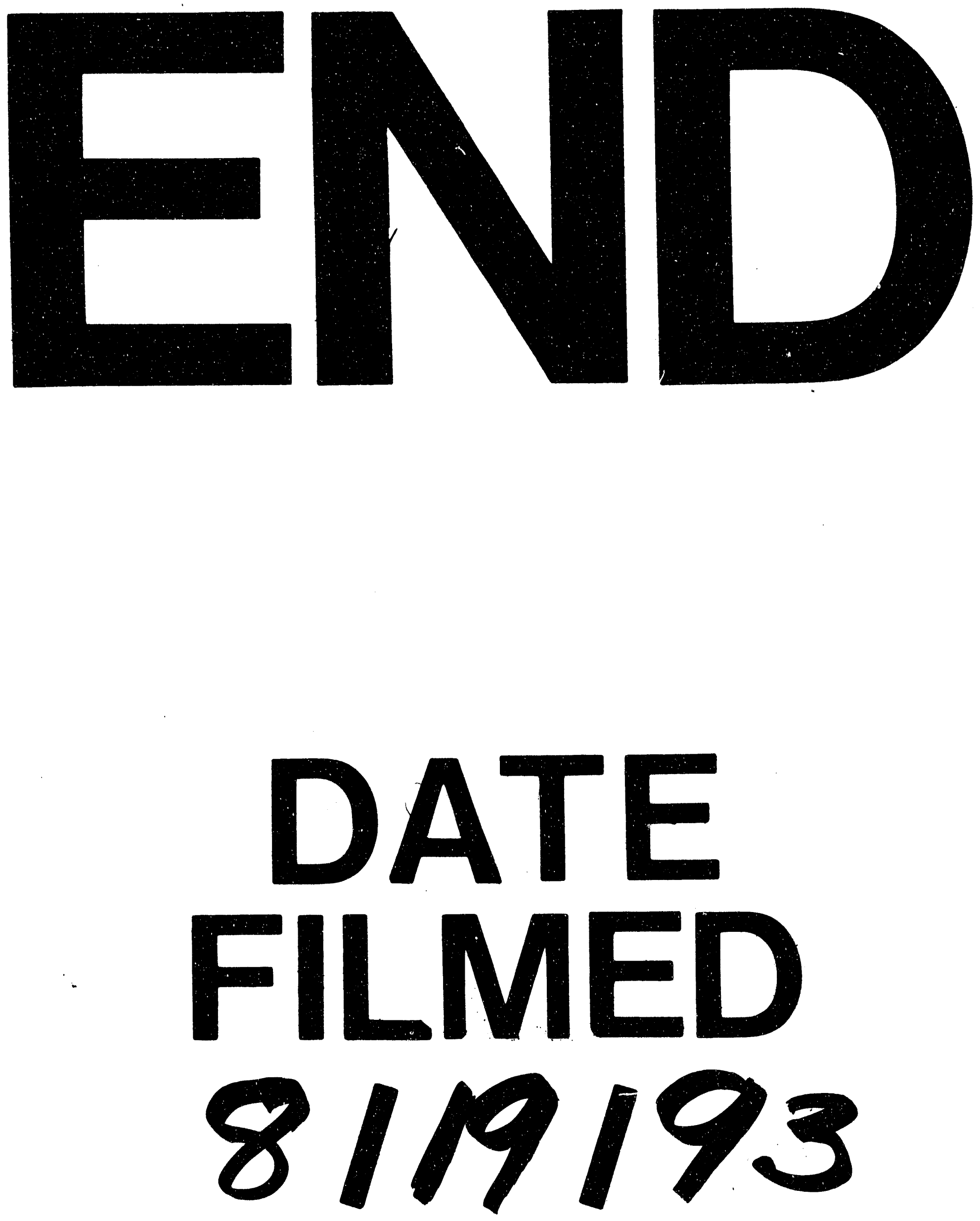
